\title{
Economic Empowerment of Women in Lebanon
}

\author{
Bassam Charif Hamdar $^{1 *}$, Hussin Hejase ${ }^{1}$, Fadi El-Hakim ${ }^{1}$, Jessica Antonios Le Port ${ }^{1}$ \& Rebecca \\ Baydoun $^{1}$ \\ ${ }^{1}$ Faculty of Business and Economics, Department of Economics, American University of Science and \\ Technology, Beirut, Lebanon \\ * Bassam Charif Hamdar, E-mail: bhamdar@aust.edu.lb
}

\begin{abstract}
This research discusses the importance of the economic role of the working woman in Lebanon. It discusses the revolution of the changing role of the Lebanese woman from being a mother and a wife, to being an important contributor to the economic growth. It highlights the effective impact of this changing role on the family stability, following the Lebanese woman integration into the working force which results in decreasing the dependency on the male partner in providing essential family needs.

Furthermore, this paper tackles the cultural differences among Lebanese women, the ambitions, the values, and the priorities of Lebanese women. It touches also on the economic empowerment of woman, who plays a significant role in facilitating the achievement of a higher level of economic welfare. However, the main focus of this paper is on the socio-economic role of the woman in the global environment where material needs have become a priority and an ultimate value.

Questions which to be addressed by this paper are: should oriental women devote their lives to material gains even if it is done at the expense of the family life? How economically important to promote the women's role as leaders and managers fully devoted to economic growth and money earnings? Are working women economically independent?
\end{abstract}

\section{Keywords}

empowerment, Lebanese women, working force, economic welfare, Lebanon

\section{Introduction}

The integration of women into the labor force has meant less dependence on men, because these women can take over jobs, earn money and meet the daily needs of life. This integration has widened the intellectual pool in social, political and economic debate. Not to mention that the appointment of women in administrative posts shattered myths that the domain of politics and leadership in public sphere is purely for men (Daily, 2009).

Dealing with the problem of women and economic development, as they take their place in the labor market, there are a number of issues to which one must research, i.e., pay equity, the "glass ceiling" principle, work and family balance, and women in a learning society.

Over recent decades, there has been a rapid increase in the number of women entering the workforce. 
However, in the orient most people continue to believe that a woman's place is at home, taking care of the family and managing the domestic world. World War II had brought a complete reversal of this trend when women were hired to fill the positions of men who were in combat. They had to take jobs in construction, airplanes, ships, and gun production. They took over the production lines in factories, and even used to work as nurses, doctors, and radio operators. As a result, many women tried to fight for their destinies and entered the workforce; they even replaced men's jobs and showed high levels of productivity and responsibility in handling such jobs (Standlee, 2010).

Today, women are struggling to show their capabilities and to prove to their partners that they can survive without even relying financially on them, and they are powerful in aligning their home duties (being a mother, wife, household organizer) with their jobs (Daily, 2009).

Women's economic participation and empowerment are fundamental to strengthen women's rights and enable them to exert influence on society. Women often face discrimination and persistent gender inequalities; moreover, some women experience multiple discrimination and exclusion because of factors such as ethnicity, caste, religion, nationality and gender. Social changes have also contributed to the rise of women participation in the work force, at the same time, the institution of marriage has undergone significant changes during recent decades. Marriage was regarded as a community where harmony was a key element in its stability and continuity. However, when women had entered the workforce, and had become as much important as men in building the society and the economy, they have become more ambitious, pursuing higher education, and looking for higher positions to be financially independent. These trends in turn have contributed to a gender role reversal in the gains from marriage.

The goal of this paper is then to highlight the effective role of women in increasing their economic empowerment and the major reasons that brought them to the workforce. The demand for women participation has increased dramatically after WWII, and the decline of the family income especially during the depression periods of the1970's and 1980's, pressured women to join the workforce to sustain the family income and protect the family from falling prey to poverty. This had led to the decline of the traditional form of marriage which forced women to seek higher educational levels, and to obtain more skills so that they may become more competitive in the work force (Karen, 2001).

Finally, a question remains in order, whether the family responsibilities that are born with women might constrain their ability to fully achieve their employment ambition.

\section{Historical View}

The main concern here is the change in the women's role in society from the traditional roles of being housewives, mothers or daughters, and from traditionally doing specific work such as teachers, secretaries, nurses, etc. to essential roles as full partners in the society. This paper follows up on the Lebanese women struggle to enter the work force as equal to their male partners. 


\subsection{Industrial Revolution}

The roots of modern feminism go back to the industrial revolution of 1800. In 1807, U.S. President Jefferson signed the Embargo Act, which stopped all trade between Europe and America following the war between Great Britain and America. As a result, importing and exporting stopped between these continents. In 1814, Francis Cabot Lowell from Boston established the first modern factory, and changed the way things were done. He hired single women instead of men for being less expensive by accepting lower salaries for the same jobs. But he faced a real obstacle in convincing the parents of women's laborers to permit them to work (Thomas, 1990).

To resolve the problem, he built what was called a boarding community where the women workers lived and worked together and assured their families that they would be protected and disciplined.

By 1850 most of the country's goods were made in factories causing a rapid migration of people from the country to the city especially single women who had no responsibilities except to prevent their families from falling to poverty.

Then, it became a must for single women to work outside home and many women started delaying marriage even for longer periods, while others decided to stay single. However, married women in contrast stayed at home and dedicated their time to raise their children and to take good care of them and their husbands. In 1900 less than 5.6\% of all married women worked in factories (Thomas, 1990).

\subsection{Women Struggle to Gain Political Voting Power}

In addition to the various opportunities that women were considered for, nevertheless, the greatest opportunity of all was the American women's right to vote which was finally guaranteed in 1920, by the ratification of the Nineteenth Amendment to the U.S. Constitution. This achievement crowned a movement that went on for more than seventy years. Many debaters foresaw the great change in politics that women voters could cause.

As a result, many politicians became nervous especially after a number of women's organizations united together to form the women's Joint Congressional Committee that represented 10 million members. This came after the declaration made by the woman who led the final fight "Carrie Chapman Catt", claiming an equal voice with men nothing less (McCulloch, 1929).

\subsection{World War I}

World War I was a catalyst that changed the life of women; it gave women the opportunity to prove themselves in a male-dominated society instead of staying at home, and doing their routine jobs. With so many men volunteering to join the war, there was a large gap in employment and an opportunity for women to fill it and replace men in their jobs (Karen, 2001).

\subsection{The Great Depression}

As the unemployment rate during the Great Depression exceeded 25 percent of the work force, women had to step aside sending their husbands and fathers to work. A large number of wives sought to participate in the workforce in order to help their families from falling into poverty. But women were given the jobs that men did not take. So, almost $15 \%$ of women were active in the workforce by the 
beginning of the WWII (Feinstein, 2006).

\subsection{World War II}

Public opinion was generally against the working of married women. The media and the government started a fierce propaganda and a campaign to change this opinion. The federal government told the women that victory could not be achieved without their entry into the workforce. Working was considered part of being a good citizen, and a working wife was a patriotic person (Standlee, 2010).

\subsection{Post World War II}

World War II marked a turning point to the distribution of economic roles between women and men in the twentieth century. However, during the 1950s, the mass media promoted an image of family union that defined the mother's role as central to all domestic activities. So many women went back to look after their families as housewives. But this situation did not last long since women from lower economic ranks had to remain in the workforce because of economic necessity. So Many women returned to work to subsist and help their husbands. A baby boom trend took place during the 1950s. Women who returned home dedicated their lives once again to their children. But around the same time an important change had come in the American life. This was the spread of the television. By 1960, $90 \%$ of the population owned at least one set. Families would gather around the screen for entertainment (Feinstein, 2006).

\subsection{Today}

The majority of women still work at the lower levels of the economic pyramid. Most are employed in clerical positions, factory work, retail sales, or service jobs. Around $50 \%$ of the workforce is female. While about $78 \%$ of all cashiers and $99 \%$ of all secretaries today are female, only $31 \%$ of managers and administrators are female. Equality in the workplace has been a mirage but it has conned millions of women into leaving their homes and destroying the family structure. It was only when economic or political factors made it necessary to get more workers that women were called to work (Daily Star, 2009).

\section{Gender Differentiation and Family Roles}

\subsection{A Theoretical Perspective on Gender}

There are many theories explaining how gender behavior did emerge. Three most important models will be discussed, including biological, social and cultural, and structural models. Each perspective explains the causes that lead to different behavior among men and women:

1) The biological model: the development of the biological model is based on the biological differences between men and women influencing the behavior among them due to differences in the genetic and physical factors. Traditionally, the brain size was used as the only indicator of intelligence level. It was assumed that women have smaller brains and so should be less intelligent than the other gender. However, this assumption was proved to be based on unsubstantiated claims (Mikkola, 2012).

2) The socialization model: it suggests that sexual identity and the differences between women and men Published by SCHOLINK INC. 
are acquired by the way humans passed through various stages of development. It recognizes the differences between men and women that emerged in the process of social and cognitive development assuming that men and women behave differently as a result of the learning environment (Denhart \& Jeffress, 1971).

3) The structural-cultural model: this approach focuses on the social structure, arrangements and environments that define and support gender differences and the reasons why society supports boys and girls to learn these messages (Abercrombie \& Turner, 2000).

\subsection{Gender Differentiation in the Workplace}

Sex and gender are often used interchangeably. The term sex is defined by the "biological differences in the genetic composition and function. While gender, reflects interpersonal and social aspects of masculinity and femininity” (Cleveland, Stockdale, \& Murphy, 2015).

At the interpersonal level, gender teaches us the proper way we should behave and interact with others. Often, when men and women behave in the same way, their behavior is interpreted in very different ways. However, there is evidence that the behavior by men and women can raise different reactions by others. It is also known that, in the work field, there's some work called "women's work" and other work known as “men’s work” (Cleveland, Stockdale, \& Murphy, 2015).

\subsection{Gender Stereotypes and Attitudes}

Even today, the influence of stereotyping on women's capacities and capabilities render women not eligible to be hired for senior positions, nor can they be leaders as men, they can only be followers and controlled by them. Gender stereotypes still harm women and are biased to men (Whitley \& Kite, 2010).

\section{Traditional Gender Traits and Roles:}

Men

Aggressive, active, competitive, strong

Courageous, rough, hence dominant

Reserved, emotionally distant
Women

Passive, noncompetitive, quiet

Compliant, submissive

Emotional, easily having feelings hurt

Stereotypes are harmful to every human being. When women and men are demanding roles providing leadership and management positions, evaluations are influenced by expectations related to gender in the context. Women in professional roles, traditionally reserved for men, can be placed in a stalemate called the double threat to performance based on how they are perceived (Rosenkrantz, Vogel, Bee, Broverman, \& Broverman, 1968).

Sackett, DuBois and Noe (1991) found that when women accounted for less than twenty percent of the working group, the evaluation of their performance was significantly lower than those received by men. So as the number of women increases in groups, they will receive slightly higher ranking. These results suggest that the psychological satisfaction of women and their positive attitudes appear to be based on the number of women in any given organization. In so, the gender composition of the organization may be a factor that influence the number of women leaders who can reach higher positions in organizations. 


\subsection{The Changing Nature of the Family}

Gender roles have undergone many changes over decades, they can be described as the attitudes and behavior expected of men and women in society (Evans, 1987).

\subsubsection{Traditional Families}

Traditionally, the experience of marriage and motherhood dominates the life and identity of women. Family structure was described as family male-oriented. Women were described as being distinct, pure and counted to be unstained. A woman was fulfilling her role as a wife, a mother and a builder of home. However, men were viewed as breadwinners for the family; they had to go outdoors to work, to provide the income of the family. The followings are the changes that shaped the new nature of today's families: a) Economic changes: starting from the depression period, passing by the economic recession, many men lost their jobs and stayed home. This pushed women to integrate in the work force in order to save their families and provide them with the basic needs (Blair \& Johnson, 1992).

b) Social changes: changes in role of family genders were viewed as being difficult since everyone has a unique role to play in order to protect the family and save it. However, the revolution took place in the workforce, provided women with self-confidence to control their lives and be independent from the other partner. Nowadays, women have more liberty and freedom to choose whether to enter the workforce, or stay at home playing their traditional role as a caregiver, mothers and wives (Helm, 1977).

\section{Economic Empowerment of Women}

Economic empowerment is referred to as a capacity of both genders to participate in, contribute to and benefit from growth processes in ways that identify the value of their contributions, respect their dignity and make it possible to negotiate a fairer distribution of the benefits of growth. Women's economic empowerment is a human right and a social justice issue, which facilitates women's participation in resource allocation, and contributes to reduce poverty rates and gender inequality. Economic empowerment increases women's access to economic resources and opportunities including jobs, financial services, property and other productive assets, skills development and market information (IDRC and DIFID).

Women's economic empowerment is the most important factor which contributes to gender equality and enhances women's living standards. In addition, it gives them the freedom to choose the way they live and how to influence the society. This process of empowerment is contingent upon the availability of resources and the ability to use them; access to economic opportunities; and the control over economic benefits.

Empowering women economically will reduce the impacts of the economic crisis and will lead to economic resilience and growth. However, women are in some contexts bearing the costs of recovering from the crisis, i.e., facing the loss of jobs, working under poor conditions, and experiencing increasing precariousness. 


\subsection{Four Strategies for Achieving Gender Equality and Economic Empowerment}

Four strategies those contribute to achieve gender equality and women's economic empowerment:

1) Achieving equal access to health and education services.

2) Increasing women's voice in sharing resources and participating indecision-making process.

3) Enhancing women's economic empowerment policies and improving the living standards of women.

4) Eliminating violence against women at home, and in their communities.

\subsection{Aspects of Empowerment}

Emphasizing what was mentioned above, one would conclude that the ability of women to control and lead their lives is a key requirement for the success of the process of empowerment. This may involve a wide range of aspects, which can be grouped in different ways as follows (Mayoux, 2000; World Bank Institute, 2001):

1) Access to and control over various resources material and non-material resources.

2) Participation in and power over various market and non-market processes and activities at different levels in society.

However, there are three categories of empowerment: political empowerment, economic empowerment, and social/legal empowerment:

a. Political empowerment is defined as increasing the participation of women in legislative assemblies, their decision power in these assemblies, the ability of women to publicly voice their opinions and to affect the composition of legislative assemblies. Social and legal institutions still do not guarantee women equality in basic legal and human rights, in access to or control of land or other resources, in employment and earning, and in social and political participation. Laws against domestic violence are often not enforced on behalf of women.

b. Economic empowerment: the primary factor of this type of empowerment is the ability of women to involve into employment of formal parts, self-employment, borrowing, saving and access to and control of economic resources. Examples of economic empowerment would be an increase in women's control of household resources or an increase in women's access to borrowing in the financial markets.

c. Legal/social empowerment: this aspect is often emerged under the concept "empowerment" it is defined under the status of women whether single or married including their social conditions and their rights as stated by law. Key aspects in this group are legal rights, status and norms. Examples of legal empowerment include: the removal of legislation which constrains women from divorce, and assistance directed at supporting women in the battle for their legal rights.

\section{An Overview of Gender Inequality in Lebanon}

Gender inequality implies a society in which both genders do not enjoy equality in outcomes and equality in opportunities (Thomas, 1990).

Therefore, gender inequality is an important issue considered as being a universal feature in developing countries including Lebanon. Women's voice in developing countries are stifled by cultural factors 
where they became silent, unlike women in developed countries who are economically, legally, and culturally empowered and have a powerful voice. Gender inequality, equal rights and equal opportunities have been affected by economic and cultural factors.

For example, religiously speaking, genetic laws differ between Muslims and non-Muslims. Where the Islamic religion gives more precise details of how the inheritance should be distributed. Muslim Women may inherit from their fathers or mothers or husbands or children or in some cases from other family members, but they get less than the share of men. To non-Muslims, the code of inheritance states that men and women inherit equally, despite the fact that customs and cultural practices favour male heirs.

Limited access to education and thus to employment reduces the women decision making power role in the society and at home. Internationally, their participation in national parliaments has been increasing yet no single country in this world has achieved complete gender count equality. In addition, and in accordance to the millennium indicators data base of UN (2005) shows women occupying $16 \%$ of parliamentary seats worldwide, $21 \%$ in developed countries and $14 \%$ in developing countries. This low representation of women in national parliaments could be due to women's social and economic status, socio-cultural traditions and beliefs about women's place in the family and society, and women's double burden of work and family responsibilities (UNFPA, 2005).

\subsection{Lebanon}

Structure of Society: Lebanese society is riddled with economic, political, social and sectarian divisions. The principal object of loyalty and the basis for marriage and social relationships are primary identified by Lebanese people who live in a society divided by sectarian issues and socio-economic layers including:

a. The family;

b. Gender roles;

c. Marriage, taboos and laws.

\subsection{The Family}

In Lebanon, family comes first in all cases especially; it backs up the individual and grants him/her political power, money and other forms of support.

\subsection{Gender Roles}

The Lebanese family assigns different roles to every family member. Its structure is patriarchal; a father's role is defined to be the producer and the breadwinner upon whom the family members depend. Moreover, he is the property owner and the master of family decisions.

In contrast, the woman's role is limited to those of a mother and a homemaker, despite the fact that women were used to participate in peasant work. However, the Lebanese society has given a great chance to women to play a more active social role, and allowed them to enter the workforce. Moreover, Lebanese women enjoy better civil rights than those of other Arab countries (Anderson \& Baland, 2002). 


\subsection{Marriage}

In the past, the rule of marriage was within the lineage, where the preference for marriage of any woman was directed towards patrilineal first cousin or one relative in order to preserve the property family property and reduce tensions. Consequently, women felt secured living with whom they are relatives.

However, in some conservative Muslim and Christian Lebanese villages, the choice of marriage is considered by the father and is obligatory, where no negotiation or rejection is allowed. In contrast, in Roman Catholic law the marriage of persons within the same bloodline is explicitly forbidden; the women are also free to choose their husbands.

\section{Methodology}

This paper investigates the empowerment of women. It utilizes a descriptive research design to determine the degree of empowerment, and to provide insights into the ways in which Lebanese women may be empowered.

\subsection{Research Locale and Respondents}

Since Banque du Libanetd' Outre-Mer (Blom bank) is one of the largest banks in Lebanon. It was chosen as a case study for having branches all over the country. The study covered all Blom employees in the regions including: Beirut, Beirut Suburbs, South Lebanon, North Lebanon and Beqaa. The collected data for 500 women was analysed using SPSS Version 17.0.

Respondents were approached to complete a one-page survey. The respondents were informed that their results would be anonymous and confidential.

The first part of the questionnaire was quantitative and focused on demographic data included as marital status. The second part relates to the perceptions of the respondents on women's contribution to the family welfare and the degree of economic independence.

\subsection{Research Instruments}

The survey was based on a questionnaire that determined the profile of the respondents specifically the gender and marital status. Through such an instrument the respondents' level of empowerment had been measured.

\section{Results and Discussions}

This part of the thesis highlights the interpretation and analyses of the results of the survey questionnaire solicited from respondents.

\subsection{Responses Analyses}

The responses Analyses is divide into two sections: the first is the distribution of the responses among the demographic aspects, and the second is the variables that answer the research questions and concerns. 


\subsubsection{Demographic Aspects}

"Question 1: gender classification by the respondents"

Table 1. Respondents by Gender

\begin{tabular}{lllllll}
\hline$\%$ & BEIRUT & S.B & M.L & BEKAA & S.L & N.L \\
\hline MALE & $20 \%$ & $35 \%$ & $50 \%$ & $60 \%$ & $50 \%$ & $55 \%$ \\
FEMALE & $80 \%$ & $65 \%$ & $50 \%$ & $40 \%$ & $50 \%$ & $45 \%$ \\
\hline
\end{tabular}

Table 1 indicates that the majority of the female respondents came from the Beirut and Beirut Suburbs regions. However, Mount Lebanon and South Lebanon statistics showed a clear balance in the gender employment.

In Beqaa, it is evident from Table 1, that the slight majority of respondents are male. Similar to Beqaa, the majority of the respondents in north Lebanon are males with 55\%, and the remaining $45 \%$ are females.

Why in the Beqaa and North Lebanon, the female rate is lower?

One of the most important causes of this inequality is due to the "wrong-practice" of the religion doctrines. While the majority of people in the Beqaa and North Lebanon are misusing the Islamic Laws, girls are taught that their primary role is to raise children and take care of the household. According to their Culture and beliefs, a woman's place is at home and a man's place is at the workplace. The Islamic law allows women to work, provided it does not lead to her neglecting her essential duties of homemaking.

It is mainly middle-aged women with relatively older children belonging to a certain group, who attempt to start an enterprise. Other women find themselves prevented by social pressure from working independently outside the house, and do not even attempt to start their own business.

Although the status of Lebanese women has improved over recent years, to some extent within the socio-cultural context-they still do not fully participate in development activities. Reality remains quite complex. The evolution of practices and mentalities seems to be far ahead of changes in the discriminatory laws, which would enable women to take up economic activities outside the home.

"Question 2: classification of the respondents based on their marital status"

Table 2. Respondent's Marital Status

\begin{tabular}{lllllll}
\hline$\%$ & Beirut & S.B & M.L & BEKAA & S.L & N.L \\
\hline Single & $30 \%$ & $65 \%$ & $65 \%$ & $50 \%$ & $60 \%$ & $50 \%$ \\
Married & $65 \%$ & $35 \%$ & $25 \%$ & $45 \%$ & $35 \%$ & $30 \%$ \\
Divorced & $5 \%$ & $0 \%$ & $5 \%$ & $5 \%$ & $5 \%$ & $10 \%$ \\
Widowed & $0 \%$ & $0 \%$ & $5 \%$ & $0 \%$ & $0 \%$ & $10 \%$ \\
\hline
\end{tabular}


It is obvious from Table 2, that the majority of the respondents in Beirut region are married with $65 \%$. In contrast, in Beirut Suburbs and in Mount Lebanon, the majority are single with 65\%. In addition, the Beqaa region shows slight similarities in results. The Southern region showed the majority of respondents to be single with $60 \%$.

Moreover, in the Northern region $50 \%$ of respondents are single, thus, the majority in these regions are single. So, why the numbers differ in different regions?

In the 1950s and 1960s, most married women did not work outside the home, instead relying on their husbands income to support the family, in 1960, 32\% of wives were in the Labour force. By 2008, that share had risen up to $61 \%$.

The net result is that a marriage gap and socio-economic gap have been growing side by side for the past half century, and each may be feeding off on the other. Adults on the lower rungs of the socio-economic ladder (whether measured by income or education) are just as eager as other adults to marry.

Along with their greater participation in the labour force, women began to delay marriage and have fewer children. In addition, women have been faced with the challenge of balancing marriage, motherhood, and work, the changes in marriage rates are driven in large by the behaviour and attitudes of young adults, who both are delaying marriage and entering into less traditional family arrangements. The fact that young adults are delaying marriage does not necessarily mean they will never marry.

\subsubsection{Dependent Variables}

In this section, the respondents were to indicate the degree of their agreement with the statement given.

"Question 3: do you agree that working women are contributing to the welfare of the family?"

Table 3. Identifies Respondents' Opinion on the Contribution of Working Women to the Family Welfare

\begin{tabular}{lllllll}
\hline$\%$ & Beirut & S.B & M.L & Beqaa & S.L & N.L \\
\hline Strongly agree & $55 \%$ & $35 \%$ & $45 \%$ & $30 \%$ & $50 \%$ & $45 \%$ \\
Agree & $40 \%$ & $55 \%$ & $40 \%$ & $60 \%$ & $50 \%$ & $50 \%$ \\
Strongly Disagree & $5 \%$ & $10 \%$ & $15 \%$ & $10 \%$ & $0 \%$ & $5 \%$ \\
Disagree & $0 \%$ & $0 \%$ & $0 \%$ & $0 \%$ & $0 \%$ & $0 \%$ \\
\hline
\end{tabular}

As illustrated by Table 3, the results reflect some divided opinion, a significant number of the respondents (55\%) have indicated that they strongly agree with the fact that working women are contributing to the welfare of the family, while the other $40 \%$ have only agreed with this hypothesis, however the rest $5 \%$ disagreed with this statement. Thus, majority of the respondents chose Strongly Agree or Agree.

A host of studies suggest that putting earnings in women's hand is the intelligent thing to do to speed 
up development and the process of overcoming poverty. Women usually reinvest a much higher portion in their families and communities than men, spreading wealth beyond them. This could be one reason why countries with greater gender equality tend to have lower poverty rates.

Women have become more assertive in today's modern world. They are shouldering family responsibilities and are on par with men taking care of themselves socially and economically. They are successfully earning their place in society and striving hard to become economically independent.

"Question 4: do you agree that working women are economically independent?"

Table 4. Identifies the Respondents' Opinion on the Economic Independence of Women

\begin{tabular}{lllllll}
\hline$\%$ & Beirut & S.B & M.L & Beqaa & S.L & N.L \\
\hline Strongly agree & $50 \%$ & $35 \%$ & $15 \%$ & $20 \%$ & $30 \%$ & $45 \%$ \\
Agree & $40 \%$ & $55 \%$ & $65 \%$ & $70 \%$ & $60 \%$ & $50 \%$ \\
Strongly Disagree & $10 \%$ & $10 \%$ & $20 \%$ & $10 \%$ & $10 \%$ & $5 \%$ \\
Disagree & $0 \%$ & $0 \%$ & $0 \%$ & $0 \%$ & $0 \%$ & $0 \%$ \\
\hline
\end{tabular}

It is obvious from Table 4 , that $50 \%$ of the respondents are strongly agree that working women are economically independent, $40 \%$ agree and $10 \%$ strongly disagree. Thus, majority of the respondents Agree or strongly agree with this statement.

Economic independence refers to a condition where the individual woman and man have their own access to the full range of economic opportunities and resources in order to shape their own needs and those of their dependants.

“Question 5: do you believe that working women are needed nowadays in the workforce?”

Table 5. Appraisal Identifies Respondents' Opinion if Working Women are Needed Nowadays in the Workforce

\begin{tabular}{lllllll}
\hline & Beirut & S.B & M.L & Beqaa & S.L & N.L \\
\hline Strongly agree & $55 \%$ & $30 \%$ & $55 \%$ & $15 \%$ & $55 \%$ & $45 \%$ \\
Agree & $45 \%$ & $70 \%$ & $45 \%$ & $75 \%$ & $45 \%$ & $55 \%$ \\
Strongly Disagree & $0 \%$ & $0 \%$ & $0 \%$ & $10 \%$ & $0 \%$ & $0 \%$ \\
Disagree & $0 \%$ & $0 \%$ & $0 \%$ & $0 \%$ & $0 \%$ & $0 \%$ \\
\hline
\end{tabular}

It is obvious from Table 5, that the majority between all regions $55.9 \%$ of the respondents agree that working women are needed nowadays in the workforce, $42.5 \%$ strongly agree and $1.6 \%$ disagrees.

As indicated by chapter 1 , during WWII, there was a labour shortage due to the fact that men were heading off to war. The U.S. government created a campaign using the fictional character of Rosie the Riveter to lure women into working. From 1940-1945, the female labour force grew by 50\%. This also 
shifted cultural attitudes, making it okay for middle class women to work.

\section{Conclusion}

The International Monetary Fund's survey of 2006 found that "societies that increase women's access to education, healthcare, employment, credit and that narrow the differences between women and men regarding economic opportunities, could increase the pace of economic development and reduced poverty”.

Moreover, women's economic empowerment can be achieved into five major factors including:

1) Women's sense of self worth,

2) Their right to have and determine choices,

3) Their right to have access to opportunities and resources,

4) Their right to have the power to control their own lives (within and outside their homes),

5) Their ability to influence the direction of social change to create more just social and economic orders nationally and internationally.

These five factors are peculiarly pertinent to the economic orb, where the women's economic empowerment can be realized by targeting advantages and initiatives to magnify the women's economic opportunities; solidify their legal status and rights; guarantee their voice, and contribution in economic decision-making processes.

\section{Recommendations}

The following recommendations are essential to speed up the economic empowerment process of the Lebanese women:

a. Emphasize the need to solve the problems of the discriminatory behaviour, and the prejudiced attitude of men against women in the Lebanese society.

b. Eliminate the stereotypes that are based on the old and the narrow minded traditions regarding the stance of the Lebanese women in society or at the workplace.

c. Eliminating gender inequality in employment.

d. Guaranteeing women's property and inheritance rights which reinforce women's effective admission to assets and other resources required for productive financial and economic activity.

e. Promote equal citizenship role.

f. Increasing women's share of seats in the Lebanese parliament, bringing women's voice into decision making process and hastening women's enrolment in the economic agenda.

g. Furthermore, Stress the need for the empowering of the incorporation of women, as equal to men, into the formal economy, and giving in particular women the authority to take part in economic decision making process.

h. Express the need to introduce laws to protect women from all forms of violence especially domestic violence and sexual harassment. 
i. Monitoring the customs and traditions and promote only the common good of them.

\section{References}

Abercrombie, N., Hill, S., \& Turner, B. S. (2000). Social structure. The Penguin Dictionary of Sociology (4th ed., pp. 326-327). London: Penguin.

Alecea, S. (2010). Shifting Spheres: Gender, Labor, and the Construction of National Identity in U.S. Propaganda during the Second World War. Minerva Journal of Women and War, 4(1).

Anderson, K. (2001). Wartime Women: Sex Roles, Family Relations, and the Status of Women during World War П. New York: Berkley Books.

Anderson, S., \& Jean-Marie, B. (2002). The economics of ROSCAs and intra-household allocation. Journal of Development Economics, 117(3), 983-995.

Blair, S. L., \& Johnson, M. P. (1992). Wives' perception of the fairness of the division of household labor; the intersection of housework and ideology. Journal of Marriage and the Family, 54, 570-581.

Daily, S. (2009). Women's Economic Empowerment: Scope for Sida's Engagement (p. 15).

Denhart, R. B., \& Jeffress, P. W. (1971). Social learning and economic behaviour: The process of economic socialization. American Journal of Economics and Sociology, 30(2), 113-125.

Evans, R. (1987). Comrades and Sisters: Feminism, Socialism and Pacifism in Europe (pp. 66-90). Sussex: Wheat Sheaf Books.

Feinstein, S. (2006). The 1930s: From the Great Depression to The Wizard Of Oz. Berkeley Heights, NJ: Enslow Publishers.

Helm, N. C. (1977). The Feminists: Women's Emancipation Movements in Europe, America and Australasia (pp. 1840-1920). London.

IDRC and DIFID. (2014). NK-Wee Concept. Retrieved December 3, 2014 from http://www.Idrc.Ca/ En/Documents/Nk-Wee-Concept-Paper.Pdf

Jeanette, N. C., Margaret, S., \& Murphy, K. R. (2015). Women and Men in Organizations: Sex and Gender Issues at Work. Erlbaum Associates Publisher: Mahwah, NJ. Page number: iii.

Mayoux, L. (2000). Micro-Finance and the Empowerment of Women - A Review of the Key Issues.

Mc Culloch, A. J. (1929). Suffrage and Its Problems. Baltimore: Warwick and York.

Mikkola, M. (2012). Feminist Perspectives on Sex and Gender. In N. Z. Edward (Ed.), The Stanford Encyclopedia of Philosophy. Retrieved from http://plato.stanford.edu/archives/fall2012/entries/ feminism-gender/>

Rosenkrantz, P., Vogel, S., Bee, H., Broverman, I., \& Broverman, D. M. (1968). Sex-role stereotypes and self-concepts in college students. Journal of Consulting and Clinical Psychology, 32(3), 287-295.

Sackett, P. R., DuBois, C. L., \& Noe, A. W. (1991). Tokenism in performance evaluation: The effects of work group representation on male-female and White-Black differences in performance ratings. 
Journal of Applied Psychology, 76(2), 263-267. http://dx.doi.org/10.1037/0021-9010.76.2.263

Thomas, D. (1990). Intra-Household Resource Allocation. An Inferential Approach. Journal of Human Resources, 25(4), 635-664.

UNFPA. (2005). State of World Population-The Promise of Equality: Gender Equity, Reproductive Health and The Millennium Development Goals. Retrieved from http://www.unfpa.org/ publications/state-world-population-2005\# sthash. jsq854YJ.dpuf

Whitley, B. E., \& Kite, M. E. (2010). The psychology of prejudice and discrimination (2nd ed.). Belmont, CA: Thomson-Wadsworth.

Women at Work: The Transformation of Work and Community in Lowell, Massachusetts 1826-1860. (1979). New York: Columbia University Press.

World Bank. (2001). Engendering Development: Through Gender Equality in Rights, Resources and Voice. World Bank Policy Research Report, 21, 776. 